\title{
Spatial and temporal variation of the phytoplankton community in a section of the Iguaçu River, Paraná, Brazil
}

\author{
Menezes, VC. ${ }^{a *}$, Bueno, $N C .^{a}$ and Rodrigues, $L C .^{b}$ \\ aPrograma de Pós-graduação em Conservação e Manejo de Recursos Naturais, Universidade Estadual do Oeste do \\ Paraná - UNIOESTE, Rua Universitária, 2019, Jardim Universitário, CEP 85819-110, Cascavel, PR, Brazil \\ bNúcleo de Pesquisas em Limnologia, Ictiologia e Aquicultura, Universidade Estadual de Maringá - UEM, \\ Av. Colombo, 5790, Bl. H-90, CEP 87020-900, Maringá, PR, Brazil \\ *e-mail: viviane_cmbio@hotmail.com
}

Received May 17, 2012 - Accepted July 12, 2012 - Distributed May 31, 2013

(With 7 figures)

\begin{abstract}
The work aimed to show variations in the composition and structure of the phytoplankton community at high water and low water in Iguaçu Falls, Iguaçu River and to examine the influence of these waterfalls and environmental variables on the community. Phytoplankton samples were taken monthly during a year from two sampling stations in the Iguaçu River. A total of 408 taxa were identified, with Bacillariophyceae being the most strongly represented group. A large differentiation in the composition of the phytoplankton was observed between the sampling stations. The total richness and density of the phytoplankton groups was very low in both sample locations, as well as the Shannon diversity index, but the evenness value was generally high. No significant seasonal and spatial difference in the studied features of the phytoplankton community was seen. But, significant seasonal differences were observed when the density and richness of the algae classes were assessed separately. The heterogeneity of the Iguaçu River's characteristics between the sampling sites caused no significant spatial differentiation in the features of the phytoplankton community. However, the seasonal variation of the climatic conditions has significantly influenced the composition and structure of the community in the Iguaçu River.
\end{abstract}

Keywords: lotic ecosystem, potamoplankton, Iguaçu River.

\section{Variação espacial e temporal da comunidade fitoplanctônica em um trecho do Rio Iguaçu, Paraná, Brasil}

\section{Resumo}

Este trabalho objetivou apresentar a variação da composição e da estrutura da comunidade fitoplanctônica a montante e a jusante das Cataratas do Iguaçu, Rio Iguaçu, Paraná, e verificar a influência destas quedas d'água e das variáveis ambientais sobre esta comunidade. As coletas do material fitoplanctônico foram realizadas mensalmente, durante um ano, em duas estações de amostragem no Rio Iguaçu. Um total de 408 táxons foi identificado, sendo Bacillariophyceae o grupo melhor representado. Uma marcante diferenciação na composição do fitoplâncton entre as estações amostradas foi observada. A riqueza total e a densidade dos grupos fitoplanctônicos foram muito baixas em ambos os locais de coleta, assim como a diversidade de Shannon; contudo, a equitabilidade, de uma maneira geral, foi alta. Não foi observada diferença sazonal e espacial significativa para os atributos da comunidade fitoplanctônica. Entretanto, diferenças sazonais significativas foram observadas quando avaliadas as densidades e riquezas das classes de algas, separadamente. A heterogeneidade das características do Rio Iguaçu entre os locais amostrados não causaram uma diferenciação espacial significativa nos atributos da comunidade fitoplanctônica. Entretanto, a variação sazonal das condições climáticas influenciou significativamente a composição e a estrutura da comunidade no Rio Iguaçu.

Palavras-chave: ecossistema lótico, potamoplâncton, Rio Iguaçu. 


\section{Introduction}

Studies on lotic environments and their biotic communities are still scarce in Brazil, considering that the country has one of the world's largest fluvial networks (Borges et al., 2003; Brassac and Ludwig, 2006; Soares et al., 2007; Brasil, 2011).

Controlled rivers, that have a series of consecutive reservoirs like the Iguaçu River, are deprived of the characteristics of the River Continuum Concept, RCC (Vannote et al., 1980). A discontinuity of the physical and biological characteristics can be observed in these ecosystems. The intensity of the modifications of discontinuity will depend on the location, position in the reservoir cascade, and the dams' operation (Barbosa et al., 1999).

Different studies carried out on tropical and subtropical rivers denote the influence of climatic conditions (rainfall and temperature) on the structure of the phytoplankton community (Bovo-Scomparin and Train, 2008; Rodrigues et al., 2009; Nogueira et al., 2010). Seasonal variation in levels of rainfall in these ecosystems and the resulting increase in discharge, as well as in temperature, directly affect the seasonal distribution patterns of the phytoplankton (Soares et al., 2007).

Changes in the discharge regime of rivers have direct implications for biodiversity (Zohary et al., 2010). Frequently, the potamoplankton density is inversely proportional to the river's discharge owing to the dilution and the physical changes caused by the intense flux, which is one of the factors that alters the rivers' turbulence (Zalocar de Domitrovic et al., 2007). The rates of growth of the phytoplankton communities only reach a significant level when they superpose the dilution rate of the lotic ecosystems (Descy, 1993).

Potamoplankton is composed of algae capable of surviving different selective forces acting on these ecosystems (Margalef, 1983; Reynolds, 1988; Reynolds and Descy, 1996; Zalocar de Domitrovic et al., 2007), and is characterised by a high proportion of rare species (Rodrigues et al., 2009). They are able to indicate different types of anthropic impact, as well as playing an important role in the biogeochemical cycles. Therefore, they serve as very useful biological indicator tools for water quality (Margalef, 1983; Reynolds, 2006; Borics et al., 2007; Stevenson, 2009).

The objective of this study was to examine the spatial and seasonal structure and composition of the phytoplankton community at two sampling stations in the final section of the Iguaçu River (Lower Iguaçu), before and after the Iguaçu Falls, and to investigate the effect of the waterfalls on the phytoplankton community.

Two hypotheses were intended in the study: 1) Differences in the dynamics of the Iguaçu River before and after the waterfalls (spatial variation) affect directly the composition and structure of the phytoplankton community, reducing features of diversity, evenness, total richness and total density recorded at low water, where the river's turbulence and speed of current are greater. 2) Seasonal variation in temperature and level of rainfall can also be a structuring factor of the phytoplankton's community in this ecosystem.

\section{Material and Methods}

The hydrographic basin of the Iguaçu River presents a total drainage area of approximately $70.000 \mathrm{~km}^{2}$ and is subdivided into: The Upper Iguaçu and High Bank, Middle Iguaçu and Lower Iguaçu (Sema, 2010). The Iguaçu River is the largest river completely located within the state of Paraná. The sample section for this study is located in the sub-basin of the Lower Iguaçu.

The Iguaçu River is one of the most important rivers for the generation of electricity in Brazil, with five large consecutive reservoirs (Foz do Areia, Segredo, Salto Santiago, Salto Osório and Salto Caxias) that produce, on average, 6.550 MW (Silva et al., 2005; PerbicheNeves et al., 2011). It is around $1.300 \mathrm{~km}$ long (Sema, 2010), and in its final section (Lower Iguaçu), the Iguaçu National Park (INP) is located at Foz do Iguaçu, Paraná, where the Iguaçu Falls are formed (Figure 1).

Two sampling stations in the Lower Iguaçu were selected for study:

- Station 1 - before waterfalls, located at $25^{\circ} 35^{\prime} \mathrm{S}$; $54^{\circ} 23^{\prime} \mathrm{W}$. In this section, the average depth of the Lower Iguaçu varies between 0.90 and $4.62 \mathrm{~m}$, and has an average speed is $0.4 \mathrm{~m} . \mathrm{s}^{-1}$. Riverbanks, characterised by the presence of native vegetation shaped by seasonal semi-deciduous forest, are around $1.200 \mathrm{~m}$ wide (IAP, 2010; Maack, 2002).

- Station 2 - after waterfalls, located at $25^{\circ} 38^{\prime} \mathrm{S}$ and $54^{\circ} 27^{\prime} \mathrm{W}$. In this section, the average depth of the Lower Iguaçu varies between 8.90 and $26.40 \mathrm{~m}$, and has an average speed of $6.8 \mathrm{~m} . \mathrm{s}^{-1}$. Riverbanks, characterised by rocky walls (Argentinian side) as well as the native vegetation on the Brazilian side, are around 65 to $100 \mathrm{~m}$ wide (IAP, 2010; Maack, 2002).

Temperature of the Foz do Iguaçu municipality varies from around $3{ }^{\circ} \mathrm{C}$ to $40{ }^{\circ} \mathrm{C}$, with an average of approximately $26^{\circ} \mathrm{C}$. The climate in general is humid, mesothermal and subtropical, without defined dry seasons, having an average annual rainfall of around $1.600 \mathrm{~mm}$ (Salamuni et al., 2002; Guimarães et al., 2003).

Water samples for the analysis of the physical and chemical variables and phytoplankton were taken monthly from May 2010 to May 2011, in the Iguaçu River (Iguaçu National Park, Foz do Iguaçu, Paraná).

The samples for the quantitative study of phytoplankton community were taken directly from the water surface (depth of $20 \mathrm{~cm}$ ), and were fixed with $1 \%$ acetic lugol solution. Samples also were collected with plankton net $(25 \mu \mathrm{m})$ to assist in the taxonomic study. These samples were preserved in Transeau's solution (Bicudo and Menezes, 2006).

The qualitative study of the phytoplankton was carried out using a binocular optical microscope, and the morphometrics (length and width) of the taxa with a magnification of 400 


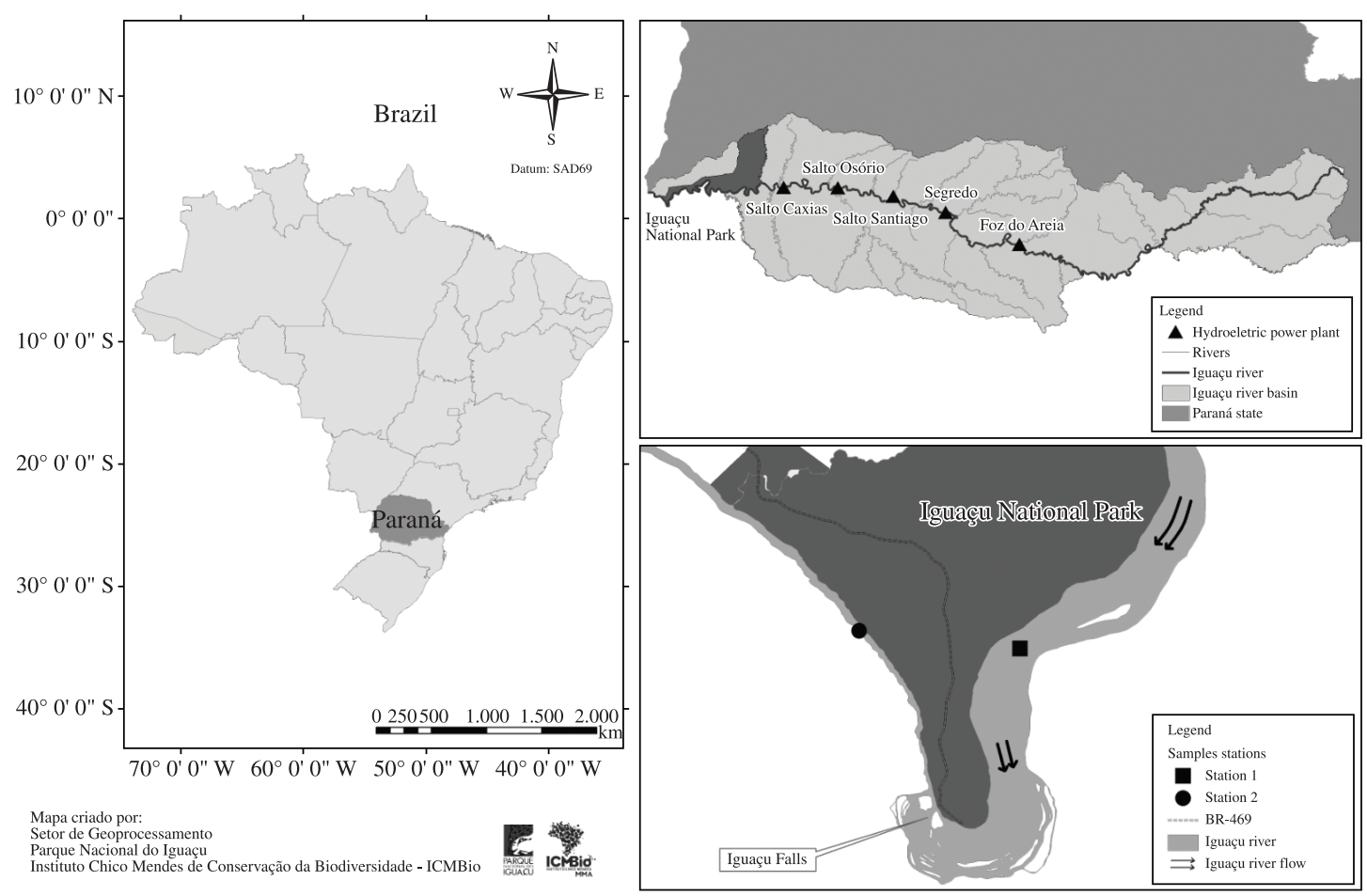

Figure 1. Location of sampling stations upstream (Station 1) and downstream (Station 2) of the Iguaçu Falls, Lower Iguaçu River, INP. Source: Division of GIS in the Iguaçu National Park.

and $1000 \times$. The systematic framework of the taxa into classes followed Komárek and Anagnostidis (1989) for the Cyanobacteria, and Bicudo and Menezes (2006) for the other groups. All the samples were deposited in the herbarium of the Unioeste - Universidade Estadual do Oeste do Paraná, UNOP, Cascavel.

The methodology described by Utermöhl (1958) was used to count the phytoplankton. The counting was carried out randomly, by fields, until 100 fields were obtained. The calculation of the phytoplankton density was carried out in accordance with the American Public Health Association (Apha, 1995). The individuals were counted in the form that they naturally occur: cells, colonies, cenobia or filaments, and the density was expressed as individuals per millilitre (ind. $\mathrm{mL}^{-1}$ ).

The structure of the phytoplankton community was described using the following attributes: richness of the species (number of taxa per quantitative sample), density (ind. $\mathrm{ml}^{-1}$ ), diversity (bits.ind. ${ }^{-1}$ ) and evenness (E).

The precipitation data $(\mathrm{mm})$ from the Foz do Iguaçu municipality was provided by the Instituto Meteorológico do Paraná (Simepar, 2011) and the data on the Iguaçu River's discharge was provided by Itaipu Binacional and Instituto das Águas do Paraná (Paraná State Water Institution).

Dissolved oxygen - DO (mg. $\left.\mathrm{L}^{-1}\right)$ and water temperature $-\mathrm{T}\left({ }^{\circ} \mathrm{C}\right)$ were obtained, respectively, in situ using a microprocessor dissolved oxygen metre, AT 150 model and a digital thermometer; $\mathrm{pH}$ with an AT-300 pH metre and, the electrical conductivity $-\mathrm{K}_{25}\left(\mu \mathrm{S} . \mathrm{cm}^{-1}\right)$ with an AT-230 model manual conductivity metre. Water transparency $-\mathrm{Z}_{\mathrm{DS}}(\mathrm{m})$ was measured using a Secchi disk and data of ammonium $-\mathrm{NH}_{4}^{+}\left(\mu \mathrm{g} . \mathrm{L}^{-1}\right)$, total nitrogen $-\mathrm{TN}$ $\left(\mu \mathrm{g} . \mathrm{L}^{-1}\right)$, nitrate $-\mathrm{NO}_{3}^{-}\left(\mu \mathrm{g} . \mathrm{L}^{-1}\right)$, phosphate $-\mathrm{PO}_{4}^{-3}\left(\mu \mathrm{g} . \mathrm{L}^{-1}\right)$ concentrations and turbidity (NTU) were provided by the AquaIguaçu program (Iguaçu Water Program Laboratory), Iguaçu National Park.

The abiotic features were synthesised using Principal Component Analysis (PCA), with the significant axes being selected in accordance with the Broken Stick criterion (Jackson, 1993). In May 2010, this analysis was withdrawn, because of the exceptional conditions caused by high rainfall at the source of the Iguaçu River, which resulted in an extremely high value for the nitrogenous forms compared to the other sample months. The PCA's axes were plotted in relation to the levels of rainfall recorded in the Foz do Iguaçu municipality, Paraná, and also in relation to the sampling stations.

The relationships between the abiotic variables (selected from the PCA's significant axes) and the attributes (density, richness, diversity and evenness) of the phytoplankton were determined using the Spearman Rank Correlation. Total density, total richness, evenness and Shannon diversity) underwent a Multivariate Analysis of Variance (MANOVA), followed by a Univariate Analysis of Variance (ANOVA), to establish the main significant effects $(\mathrm{p}<0.05)$ related to location and periods. The same procedure was adopted to assess the significant differences in the densities and 
richness by class (Bacillariophyceae, Chlorophyceae, Cyanobacteria) in the locations and time periods.

The MANOVA has the advantage of controlling the increased possibility of error type I (p-value) that occurs when carrying out more than one ANOVA for the dependent variables that have occurred in the same group of data (Scheiner and Gurevitch, 1993).

The specific diversity Shannon Index $\left(H^{\prime}\right)$ of the phytoplankton community was estimated (Shannon and Weaver, 1963), as well as evenness (Pielou, 1966).
To estimate specific diversity and evenness, and to carry out the PCA, the statistics program PC-ORD, version 4.0 was used (McCune and Mefford, 1999). Spearman's Correlation Rank, MANOVA and ANOVA were carried out using the Statistica program, version 7.1 (Statsoft, 2005).

\section{Results}

High levels of precipitation were observed in spring and the beginning of summer (September to December

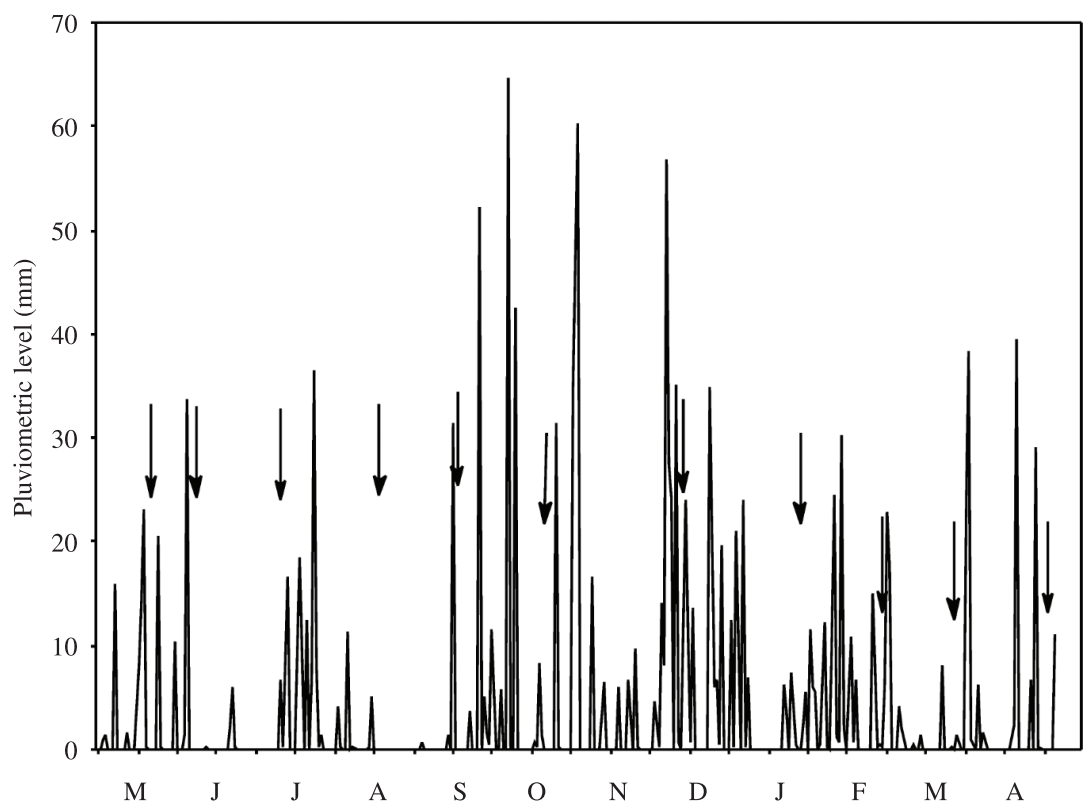

Figure 2. Daily values of rainfall recorded at Foz do Iguaçu, from May 2010 to May 2011; Sampling days (arrows).

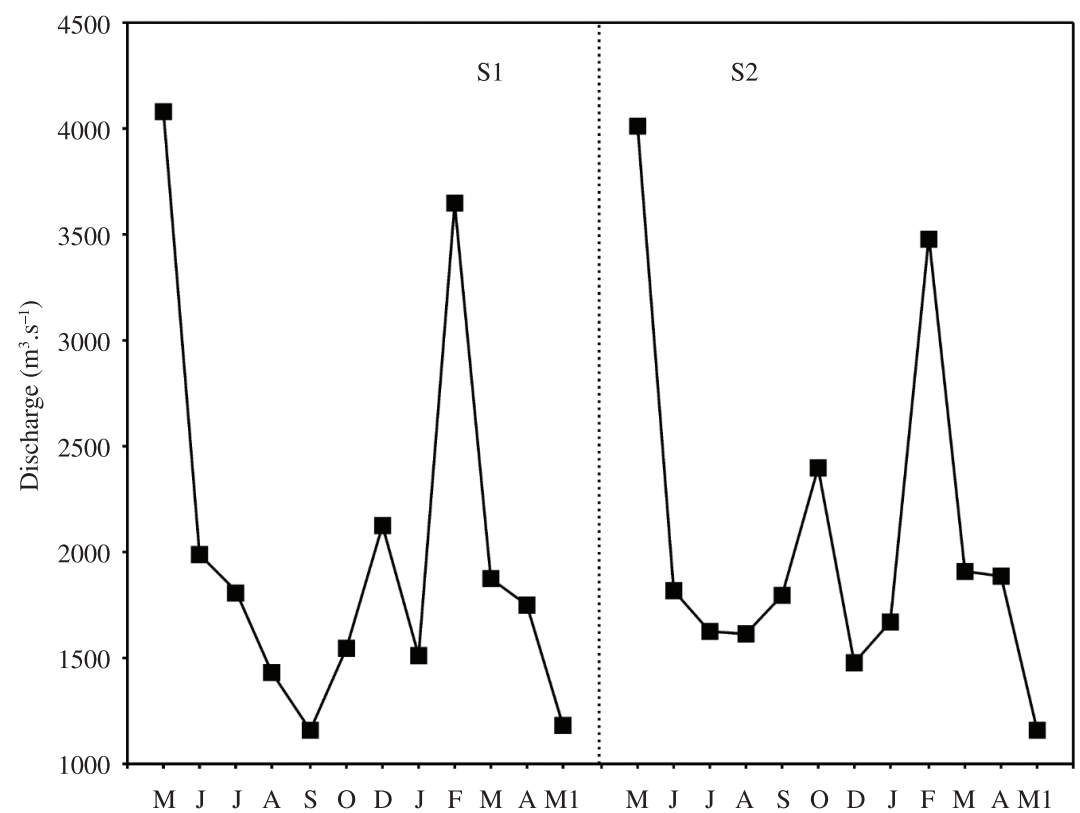

Figure 3. Monthly average discharge of the Iguaçu River upstream (Station 1) and downstream (Station 2) of the Iguaçu Falls, from May 2010 to May 2011. 
2010), and low levels of precipitation were observed in the winter, dry season (Figure 2). Regarding the average monthly discharge levels of the Lower Iguaçu at stations 1 (before waterfalls) and 2 (after waterfalls) (Figure 3), there was little spatial variability, in spite of the high seasonal variation related to the levels of rainfall, that affect the operation of the dams of the consecutive reservoirs located upstream. The lowest air temperatures were recorded in winter, in June and August 2010, and the highest temperatures between January and March 2011, in the summer.

In most of the temporal scale, the $\mathrm{pH}$ levels were close to neutral in both sampling stations, reaching alkaline in the dry season (winter), and nearly acidic values in the rainy season. The greatest DO values in the whole period of study were recorded at station 2 (after waterfalls), where the current of the Iguaçu River is greatest. The highest levels of turbidity were observed in the summer, when the level of rainfall was highest, and the lowest values were recorded in May 2011. In this period of year, discharges were the lowest in the whole period sampled (Table 1).
The lowest levels of $\mathrm{NH}_{4}^{+}$were recorded in months with the low levels of rainfall, and the highest levels in months with high levels of rainfall and discharge of the Iguaçu River. The highest levels of $\mathrm{TN}$ and $\mathrm{NO}_{3}{ }^{-}$were recorded in the period with the highest discharge (May/2010) at station 1 , whereas the levels of $\mathrm{PO}_{4}^{-3}$ presented the greatest coefficient of variation at station 2 . The other variables presented low spatial variations (Table 1).

The two PCA axes were significant (values equal to 4.0 and 2.8), and together account for $48.6 \%$ of the total variability of the data in the Lower Iguaçu. Axis 1 was positively influenced by the $\mathrm{pH}(0.37)$ and water transparency (0.34), and negatively influenced by the water temperature $(-0.33)$, electrical conductivity $(-0.37)$, discharge $(-0.36)$ and turbidity $(-0.42)$, showing a tendency of separation in the dry and rainy seasons. Axis 2 of the PCA was positively associated with the values of $\mathrm{TN}(0.54), \mathrm{NO}_{3}{ }^{-}$ $(0.47)$ and $\mathrm{PO}_{4}^{-3}(0.38)$, and negatively associated with the water temperature $(-0.32)$ (Figure 4$)$.

Table 1. Values of water temperature - T $\left({ }^{\circ} \mathrm{C}\right)$, Dissolved oxygen - DO $\left(\mathrm{mg} . \mathrm{L}^{-1}\right), \mathrm{pH}$, Electrical Conductivity $-\mathrm{K}_{25}\left(\mu \mathrm{S} . \mathrm{cm}^{-1}\right)$, Water Transparency - $\mathrm{Z}_{\mathrm{DS}}(\mathrm{m})$, Turbidity - NTU, NH ${ }_{4}^{+}\left(\mu \mathrm{g} . \mathrm{L}^{-1}\right), \mathrm{NT}\left(\mu \mathrm{g} . \mathrm{L}^{-1}\right), \mathrm{NO}_{3}^{-}\left(\mu \mathrm{g} . \mathrm{L}^{-1}\right), \mathrm{PO}_{4}^{-3}\left(\mu \mathrm{g} . \mathrm{L}^{-1}\right)$, Depth- Z $(\mathrm{m})$ e annual Coefficient of Variation (CV) in stations 1 and 2 for the sampling period.

\begin{tabular}{|c|c|c|c|c|c|c|c|c|c|c|c|}
\hline Month & $\mathbf{T}$ & DO & pH & $K_{25}$ & $K_{\mathrm{DS}}$ & NTU & $\mathrm{NH}_{4}^{+}$ & NT & $\mathrm{NO}_{3}^{-}$ & $\mathrm{PO}_{4}^{-3}$ & $\mathbf{Z}$ \\
\hline \multicolumn{12}{|l|}{ Station 1} \\
\hline May & 20.3 & 7.2 & 7.3 & 43.2 & 0.5 & 19 & 3241 & 9450 & 6770 & 1 & 2.7 \\
\hline June & 19.6 & 8.8 & 8.2 & 40.3 & 1.3 & 3.3 & 12 & 1660 & 1640 & 30 & 1.9 \\
\hline July & 18.7 & 8.5 & 7.2 & 40.3 & 1.4 & 8.0 & 12 & 1700 & 1680 & 120 & 1.6 \\
\hline Aug & 17.2 & 10.3 & 9.2 & 37.9 & 1.6 & 2.8 & 8 & 700 & 540 & 15 & 1.6 \\
\hline Sept & 22.4 & 8.3 & 8.7 & 32.8 & 2.1 & 2.0 & 13 & 252 & 953 & 17 & 1.4 \\
\hline Oct & 20.5 & 8.2 & 7.4 & 35.2 & 1.6 & 3.1 & 70 & 140 & 1003 & 5 & 1.7 \\
\hline Dec & 25.3 & 8.1 & 7.1 & 38.6 & 1.6 & 2.7 & 1 & 364 & 820 & 7 & 1.6 \\
\hline Jan & 25.4 & 4.3 & 7.2 & 39.1 & 1.3 & 7.6 & 27 & 168 & 1053 & 7 & 1.4 \\
\hline Feb & 25.4 & 4.3 & 6.9 & 40.7 & 1.1 & 26.1 & 2 & 196 & 1053 & 14 & 2.3 \\
\hline Mar & 25.5 & 7.8 & 6.8 & 38.5 & 2.8 & 7.3 & 6 & 56 & 70 & 11 & 1.6 \\
\hline Apr & 23 & 7.2 & 6.1 & 44.6 & 0.9 & 20.3 & 41 & 448 & 253 & 16 & 1.7 \\
\hline May 11 & 19.3 & 9.0 & 7.3 & 35.8 & 2.0 & 2.1 & 37 & 336 & 100 & 17 & 2.0 \\
\hline CV (\%) & 13.7 & 23.1 & 11.4 & 8.5 & 40.4 & 95.9 & 321 & 204 & 135 & 144 & 24.3 \\
\hline \multicolumn{12}{|l|}{ Station 2} \\
\hline May & 20.3 & 12.4 & 7.6 & 43.6 & 0.5 & 19 & 146 & 308 & 17800 & 420 & 17.3 \\
\hline June & 18.6 & 10.8 & 8.2 & 40.0 & 1.1 & 3.0 & 61 & 1150 & 1090 & 1 & 14.5 \\
\hline July & 19.1 & 11.3 & 7.4 & 38.4 & 2.1 & 7.7 & 24 & 620 & 590 & 50 & 11.5 \\
\hline Aug & 17.1 & 10.8 & 9.3 & 38.2 & 1.7 & 3.2 & 33 & 490 & 540 & 33 & 12.8 \\
\hline Sept & 23.0 & 7.6 & 8.3 & 34.0 & 2.1 & 3.2 & 79 & 224 & 637 & 24 & 11.7 \\
\hline Oct & 20.4 & 9.5 & 7.3 & 35.8 & 1.5 & 2.9 & 1 & 252 & 1487 & 4 & 13.9 \\
\hline Dec & 25.7 & 8.3 & 7.8 & 39.4 & 1.4 & 4.9 & 6 & 224 & 410 & 19 & 15.6 \\
\hline Jan & 25.6 & 9.6 & 6.9 & 38.4 & 1.4 & 8.4 & 22 & 140 & 220 & 6 & 18.5 \\
\hline Feb & 25.6 & 9.6 & 6.8 & 39.5 & 1.0 & 16.7 & 1 & 280 & 853 & 17 & 18.9 \\
\hline Mar & 26.0 & 7.6 & 6.8 & 42.2 & 2.0 & 8.8 & 11 & 112 & 140 & 12 & 24.3 \\
\hline Apr & 22.0 & 9.6 & 5.9 & 43.6 & 0.7 & 22.1 & 21 & 504 & 286 & 15 & 15.8 \\
\hline May 11 & 19.3 & 9.9 & 8.2 & 32.8 & 3.6 & 2.8 & 49 & 168 & 40 & 17 & 17.3 \\
\hline CV $(\%)$ & 14.6 & 14.8 & 11.8 & 8.8 & 51.2 & 80.4 & 110.8 & 78.1 & 79.7 & 892.2 & 22.5 \\
\hline
\end{tabular}




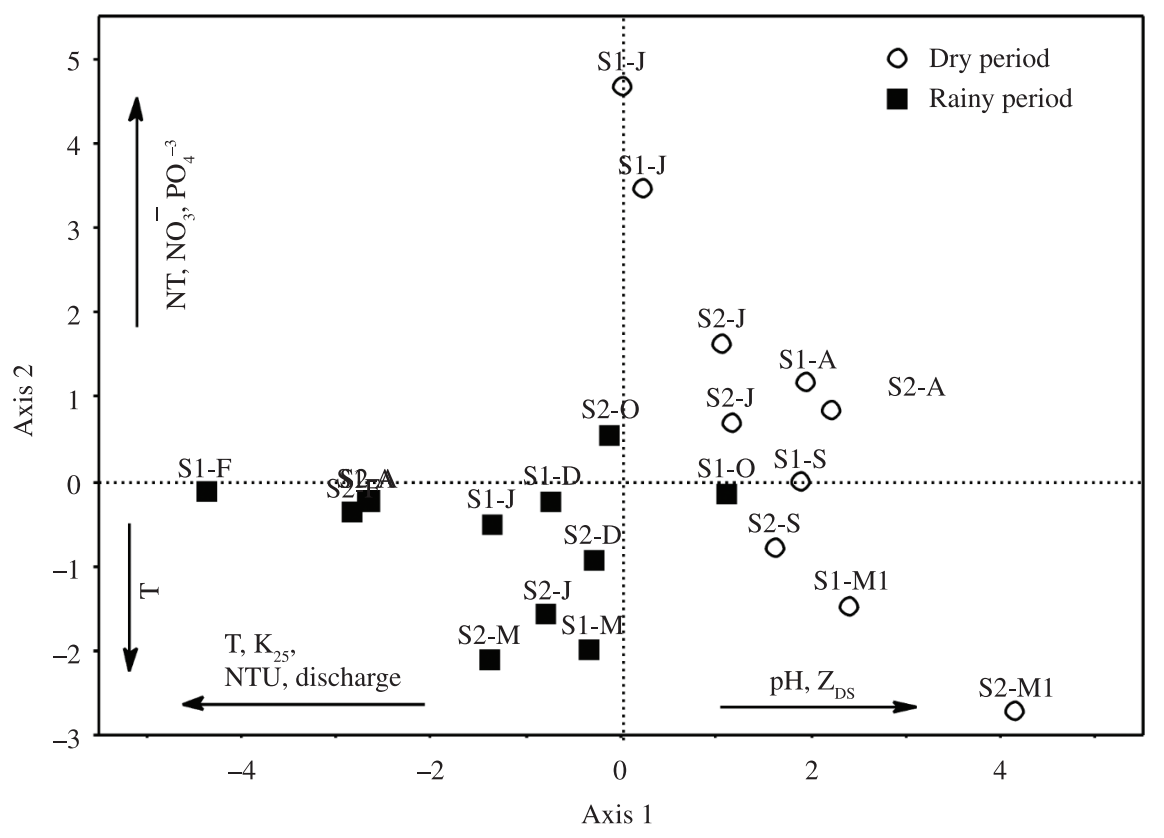

Figure 4. Ordination of months and sampling stations in the Iguaçu River in relation to the first two axes of PCA and the dry and rainy seasons (S1 - Station 1; S2 - Station 2; May-M; J-June; J-July, A-August; S-September; O-October; D-December; J-January; F-February; M-March; A-April; M1- May 2011; T-Water Temperature; NT-Total nitrogen; $\mathrm{NO}_{3}^{-}-\mathrm{Nitrate}^{-} \mathrm{PO}_{4}^{-3}-$ Phosphate; $\mathrm{K}_{25}$-Condutivity; NTU -Turbidity; D -Discharge; $\mathrm{pH}-\mathrm{pH}$; $\mathrm{Z}_{\mathrm{DS}}$ - Water Transparency.

The phytoplankton community presented an elevated biodiversity, with 408 taxa recorded. Among the taxonomic groups, Bacillariophyceae (52.2\%), Chlorophyceae (17.9\%), Cyanobacteria (10.8\%) and Zygnemaphyceae (10.3\%) produced the highest number of taxa. The other groups, Rhodophyceae, Euglenophyceae, Craspedomonadophyceae, Chrysophyceae, Oedogoniophyceae, Chlamydophyceae Dinophyceae and Xanthophyceae collectively formed $8.8 \%$ of the total number of taxa identified.

In station 1, 258 taxa were recorded, whereas a total of 344 taxa were obtained in station 2. Of the total classified taxa, 177 were common to both sampling stations, 75 were exclusive to station 1 and 159 were exclusive to station 2 .

The richness of phytoplankton species was low in stations 1 and 2, and it was made up of Bacillariophyceae, Chlorophyceae and Cyanobacteria (Figure 5a). Diatoms (Bacillariophyceae) contributed most to the richness of the environment studied and the highest richness values of Bacillariophyceae at both stations occurred in October 2010 and April 2011. Cyanobacteria were only recorded in the summer period, when there were higher temperatures (Table 1). Chlorophyceae presented a greater contribution to richness in station 1 and were only recorded at station 2 in June, December 2010 and January 2011.

The phytoplankton densities were extremely low at both sampling stations (Figure 5b). An average of 25 ind. $\mathrm{mL}^{-1}$ was recorded before waterfalls (station 1) and 19 ind. $\mathrm{mL}^{-1}$ at after waterfalls (station 2). The density during the dry season (winter) was mainly made up of Bacillariophyceae. Chlorophyceae and Cyanobacteria presented the lowest densities after waterfalls, 19 and 38 ind. $\mathrm{mL}^{-1}$ respectively.
In December 2010 (summer) at station 1, the study's highest density of phytoplankton was recorded, with a peak of 55 ind. $\mathrm{mL}^{-1}$ of Chamaesiphon (Cyanobacteria).

Low average Shannon diversity indexes $\left(H^{\prime}\right)$ were found before ( 1.56 bits.ind.$\left.^{-1}\right)$ and after waterfalls ( 1.58 bits. ind. ${ }^{-1}$ ) (Figure 6). The highest values of species diversity were recorded in October (2.1) and April (high water = 2.1; low water $=2.2$ ) at the two sampling stations. In January, they were only recorded at high water, whereas the lowest Shannon diversity indexes were only observed at station 1 in June and December.

The phytoplankton community of the Lower Iguaçu generally produced high evenness, ranging from 0.45 in December (station 1) to 1.0 in June, August, September and February (station 1) and in May, July, September and March (station 2). Thus, density of the species was evenly distributed throughout almost all of the sampled period (Figure 6).

The Spearman's Rank Correlation $(\mathrm{p}<0.05)$ showed that alterations in the structure of the phytoplankton were only observed for the density $(\mathrm{p}=-0.69)$ and richness ( $\mathrm{p}=-0.76$ ) of the Cyanobacteria, correlating with $\mathrm{pH}$, water transparency, $\mathrm{K}_{25}$, NTU and discharge (significant variables of axis 1 of the PCA).

Using MANOVA, the community's properties (total density, total richness, equality and Shannon diversity) did not differ between sampling stations (Wilks: $\lambda=0.82$; $\mathrm{p}=0.45$ ) nor in between the dry and rainy seasons (Wilks: $\lambda=0.75 ; p=0.24)$. Nevertheless, when the density and richness of the classes (Bacillariophyceae, Chlorophyceae, Cyanobacteria) were separately assessed, significant 

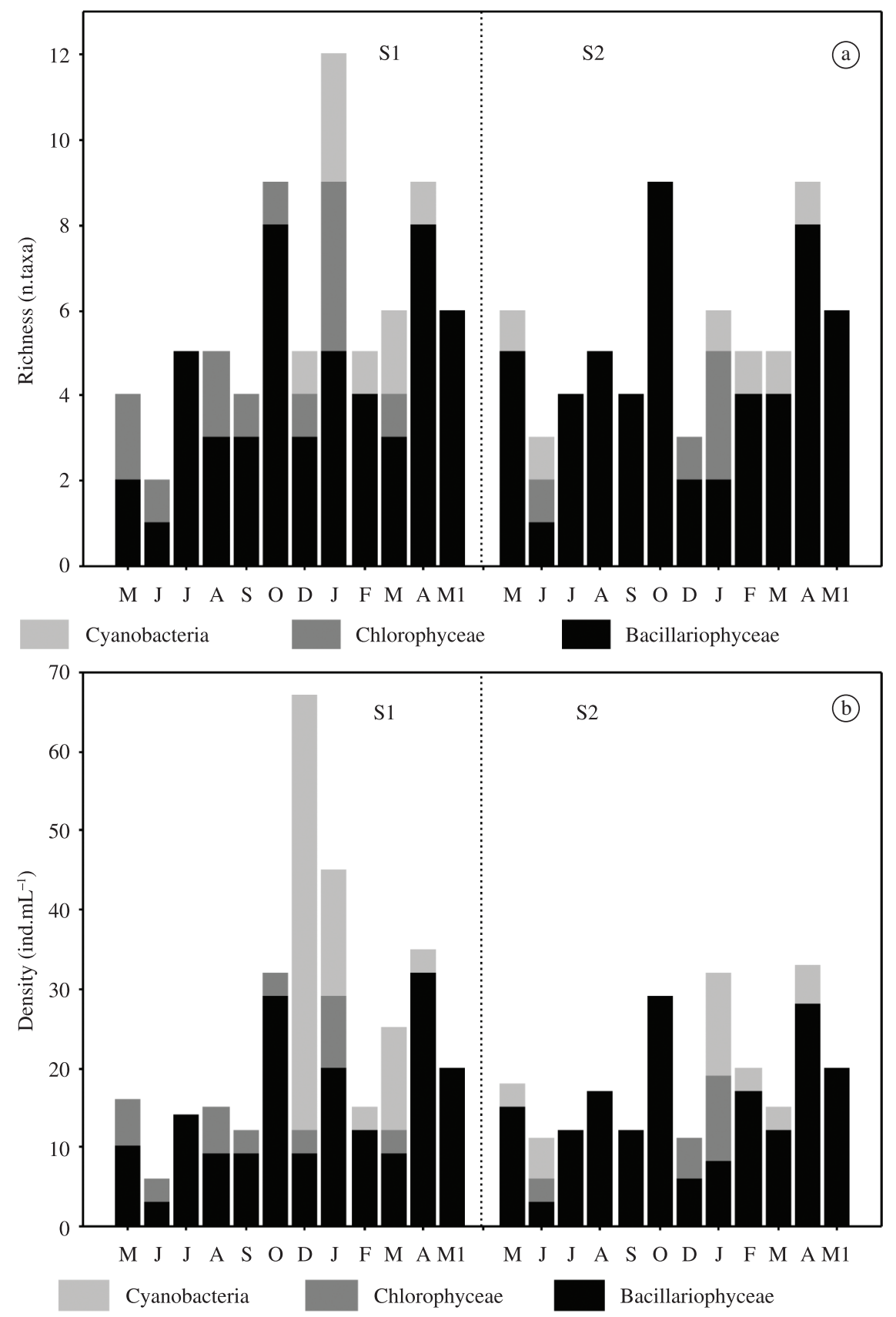

Figure 5. Monthly variation of phytoplankton richness (a) and density (b) of the Lower Iguaçu, at both sampling stations (S1-station 1; S2-station 2), from May 2010 to May 2011 (M-May; J-June; J-July, A-August; S-September; O-October; D-December; J-January; F-February; M-March; A-April; M1- May 2011).

seasonal differences on density (Wilks: $\lambda=0.1 ; p=0.02$ ) and richness (Wilks: $\lambda=0.60 ; p=0.02$ ) were observed (Figure 7). A tendency in both attributes to increase with an increase in levels of rainfall was observed. These results indicate that an influence of climatic variations was recorded on the structure of the phytoplankton community in the studied ecosystem.

\section{Discussion}

The high taxonomic complexity of phytoplankton community recorded in the Lower Iguaçu region was also observed in other rivers as the Moselle River, France (Descy, 1993), in the Corumbá River, Brazil (Silva et al., 2001), in the Nakdong River, Korea (Ha et al., 2002), in the Paraná, Baía and Ivinhema Rivers, Brazil (Rodrigues et al., 2009), 


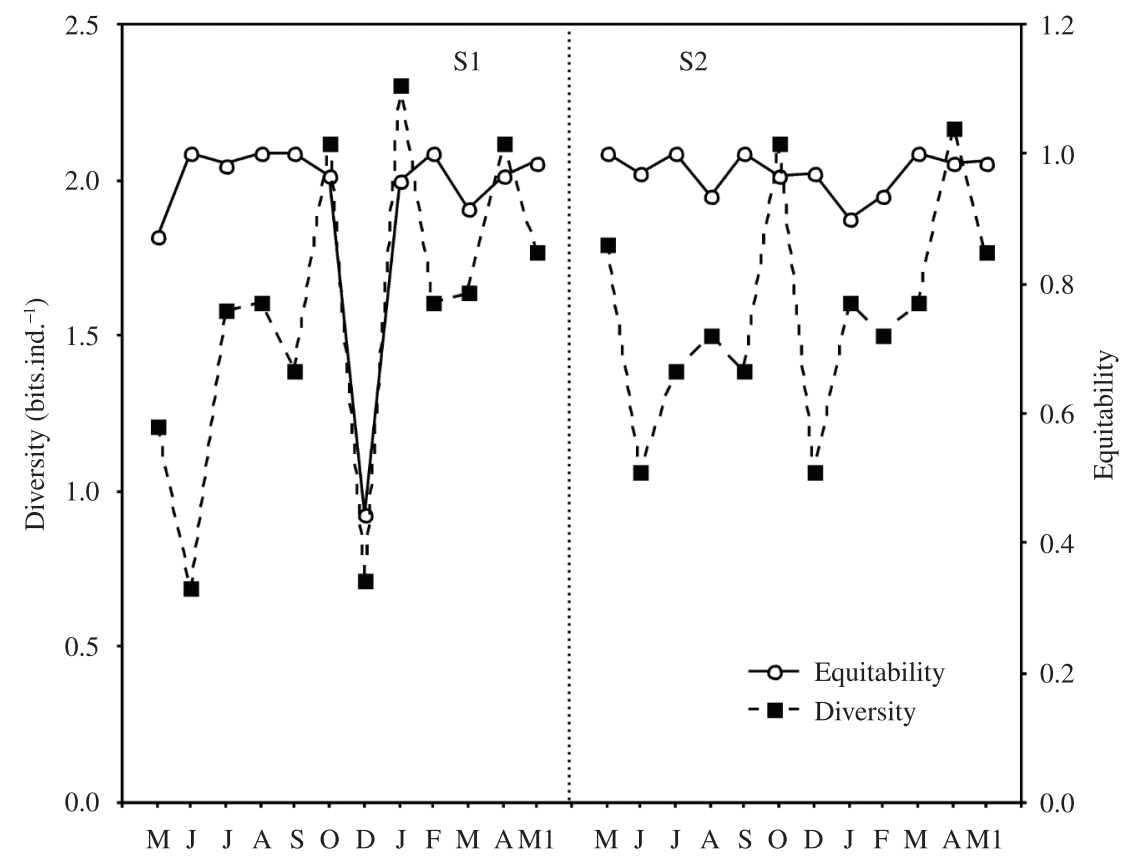

Figure 6. Monthly variation of Shannon diversity and equitability of phytoplankton at stations 1 and 2, from May 2010 to May 2011 (M-May; J-June; J-July, A-August; S-September; O-October; D-December; J-January; F-February; M-March; A-April; M1- May 2011).

in the Paraná River, Argentina (Devercelli, 2010) and in the Loire River, France (Descy et al., 2011).

As in the Lower Iguaçu, similar composition was observed by other researchers in different rivers (Descy, 1993; Wehr and Descy, 1998; Stevenson, 2009; Devercelli, 2010; Twiss et al., 2010; Descy et al., 2011). The reduced proportion of Cyanobacteria in the phytoplankton of the Lower Iguaçu (around 10\% of the total number of taxa identified) was also recorded by O'Farrell et al. (2002) in the Luján River. Cyanobacteria species are very sensitive to the high discharges observed in lotic ecosystems (Rodrigues et al., 2009).

Differences in the composition of phytoplankton in the Iguaçu River between stations 1 (before waterfalls) and 2 (after waterfalls) can be related to depth, transparency of the water column, discharge, speed of the current and turbulence. They can also be related to the different degree of adaptation of the phytoplankton species to these variations, since they present the specific physiological requirements in terms of light availability and the concentration of nutrients in the lotic ecosystems (Stevenson, 2009).

The finding of a higher number of Bacillariophyceae after the waterfalls, mainly in the order Pennales, typically benthic organisms, indicates a strong influence of the current in this sampled section (Train et al., 2000). This increases the influence of the riverbank region, formed primarily of rocky walls, with a width that is around ten times lower than that found at the site before waterfalls.

The presence of benthic (periphytic) taxa is common in lotic systems. These organisms can break away from the substrata because of the river's discharge and strong current, thus being transported by the flow of water (Lair and Reyes-Marchant, 1997; Soares et al., 2007; Stevenson, 2009). Descy et al. (2011) observed that over $70 \%$ of the species of diatom identified in the Loire River were benthic and not potamoplanktonic, like in the Lower Iguaçu.

The lower proportion of periphytic diatoms at station 1 (before waterfalls) could be related to the characteristics of the riverbanks in this section (absence of rocky walls), as well as the lower turbulence and speed of current than those observed at station 2 (after waterfalls). These factors result in reduced sediment re-suspension and causing a decreasing on the taxonomic diversity of the Bacillariophyceae.

The high presence of Bacillariophyceae, as observed in this study, has been commonly recorded in rivers (Wehr and Descy, 1998; Train et al., 2000; Ha et al., 2002; O'Farrell et al., 2002; Borges et al., 2003; Rodrigues et al., 2009). This is due to the low requirement of light availability and adaptation to turbulent environments (O'Farrell et al., 2002; Raven and Waite, 2004; Silva et al., 2005; Soares et al., 2007; Rodrigues et al., 2009).

The highest Shannon diversity values recorded at both sampling stations were observed during the rainy season (summer) and are related to the large presence of Bacillariophyceae with reference to both the richness and density of phytoplankton in the Lower Iguaçu. However, it is important to highlight that the richness and density of the Bacillariophyceae class were not only representative in the rainy season, but also in the dry season (winter).

In accordance with Cavalcanti and Larrazábal (2004), the Shannon diversity can be assessed as very low (values 

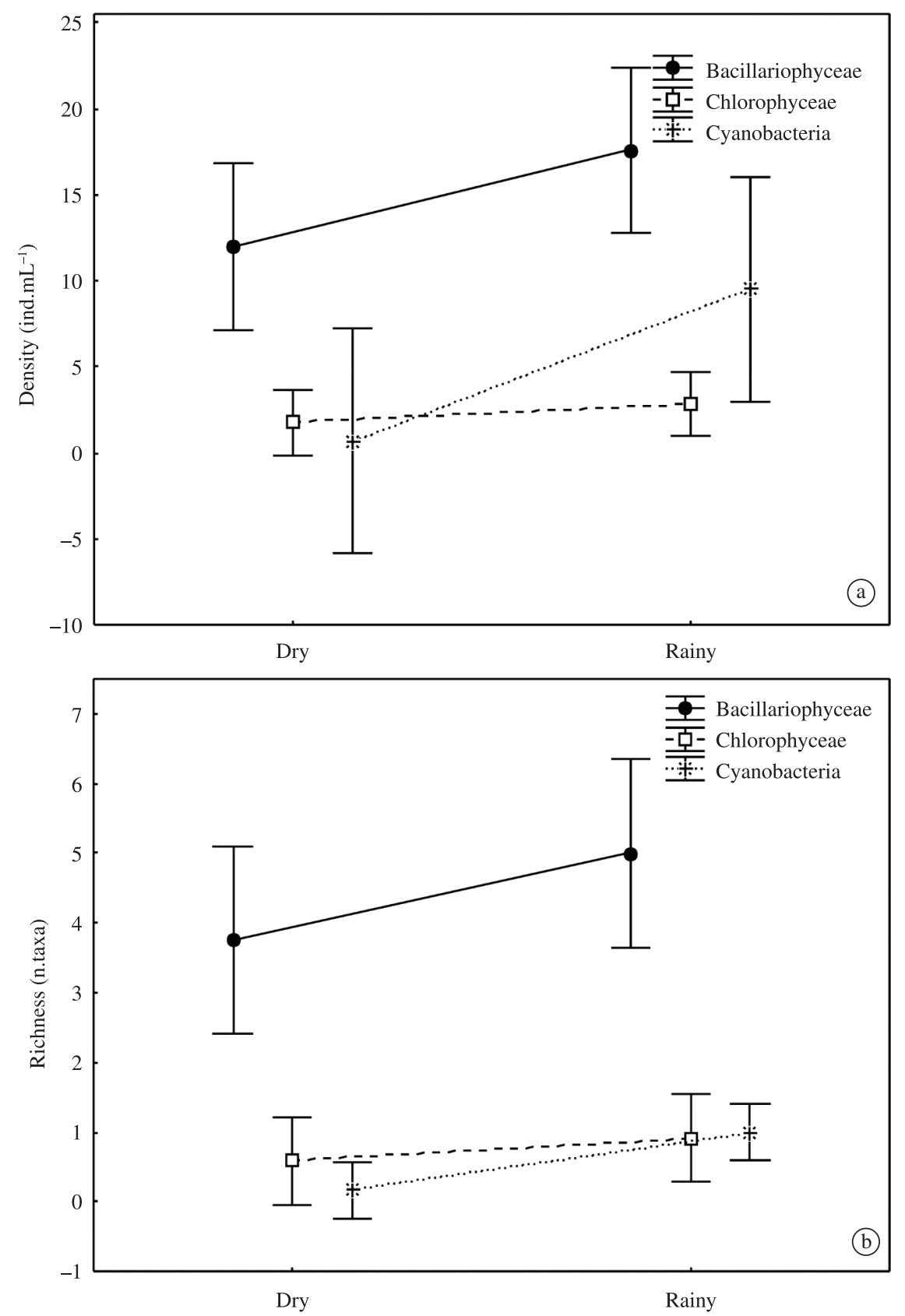

Figure 7. Variation of density (a) and richness (b) of the phytoplankton classes observed in the Lower Iguaçu, in the dry and rainy seasons.

lower than 1.0 bits.ind. ${ }^{-1}$ ), low (between 2.0 and 1.0), medium (between 3.0 and 2.0) and high (above 3.0). According to these criteria, the diversity of the phytoplankton community recorded at before and after the waterfalls of Iguaçu River, can be classified as very low to medium.

These results are expected once the studied section of the Iguaçu River is located downstream of the consecutive reservoirs damming this river. Non-cyclical disturbances produced by the operation of the dams in controlled rivers, as well as other anthropogenic actions, make the biological communities unstable and gradually simpler (Henry, 1999).

The results found in the Lower Iguaçu differ from those obtained by Devercelli (2010), where the observed average diversity in the Paraná River (Argentina) could be classified as high (3.27-3.43), and by Descy et al. (2011), where the Shannon diversity for the Loire River varied from very low (0.34) to high (5.78). In contrast to the Iguaçu River, the Paraná River (Argentina) is characterised by 
its bearing of a large amount of material in suspension, a hydro-sedimentological regime with the formation of flood plains, that increases the richness of the potamoplankton species as well as the number of sporadic species that are principally incorporated in the main channel of this river as a result of the hydrological fluctuations (Devercelli, 2010).

The phytoplankton of the Lower Iguaçu presented similar characteristics to those observed in the Pomba River (Minas Gerais), in that the diversity and richness of the species was very low (Soares et al., 2007), in the Ivinhema River (Mato Grosso do Sul), where the phytoplankton richness encompassed a high proportion of rare species and the total density was very low (Rodrigues et al., 2009), and also in the middle Paraná River (Argentina) where the phytoplankton presented a low density in normal hydrological conditions (Devercelli, 2010)

The increase in density values in December 2010, in station 1, with dominance of Chamaesiphon (Cyanobacteria) is due to the proportion of the periphytic community in the potamoplankton, mainly in periods of greater discharge and turbulence. As verified in the Luján River by O'Farrell et al. (2002), the most elevated phytoplankton density values in the Lower Iguaçu were recorded at the end of spring and beginning of summer.

Concerning the distribution of phytoplankton diversity and evenness in the environment studied, that there was a sharp variation precisely in December 2010, owing to the peak density of Chamaesiphon sp. There was a dominance of this species compared to the others, and no more homogeneity in the distribution of the phytoplankton density between the sampling stations - relatively low evenness.

The low phytoplankton diversity and high phytoplankton evenness in the Lower Iguaçu could be related to the negative correlation commonly recorded in lotic environments, between the diversity and biomass values of the phytoplankton and the high discharge (Descy, 1993). Phytoplankton richness and density tends to decrease owing to the greater rate of dilution when there is an increase in the discharge (Descy, 1993; Wehr and Descy, 1998; Zalocar de Domitrovic et al., 2007). A relatively large contribution of rare species to the richness of phytoplankton of the Lower Iguaçu also results in high evenness (Rodrigues et al., 2009).

Despite the high rate of dilution observed in certain lotic environments, the low diversity of the phytoplankton species also derives from the need for periods of stability of the water column so that some types of algae, like the Chlorophyta, can colonize these ecosystems (Stevenson, 2009). This situation is difficult to observe in rivers, since they present a continuous flux.

The results of PCA evidenced only a seasonal segregation (dry and rainy seasons) and indicated the lack of spatial differences in physical and chemical characteristics of the Lower Iguaçu's water between the high water and low water sections of the waterfalls could be related to the relatively short distances between the sampling stations (approximately $12 \mathrm{~km}$ ). No anthropic activities (industry, agriculture) in the sections close to the sampling sites, which bring about an increase in nutrient concentrations, principally nitrogen and phosphorous in the river, in contrast to what was observed in the Upper and Middle Iguaçu regions (Sema, 2010).

Nutrients in lotic ecosystems that are generally present in proportions greater than those needed by the algae (Salmaso and Zignin, 2010) and, are no limiting factor on the development of the phytoplankton, as observed in the Moselle River, France (Descy, 1993), in the Médio Paraná River, Argentina (Zalocar de Domitrovic et al., 2007), in the Adige River, Italy (Centis et al., 2010), in the Saint Lawrence River, Canada (Twiss et al., 2010), in the Loire River, France (Descy et al., 2011), and also in the Iguaçu River, for this study.

Dynamics of the potamoplankton respond primarily to the physical environmental factors, being able to present considerable variations in time and space (Descy et al., 2011). This could be the reason why the phytoplankton structure in large rivers does not frequently present strong correlations with the chemical variables of the water (Wehr and Descy, 1998).

Density and richness values of the Cyanobacteria showed a relationship the water temperature, evidencing a marked seasonality for the area of the study. The Cyanobacteria presented a significant richness and density in the summer months, when the water temperature was higher, favourable conditions for the development of these algae (Dokulil and Teubner, 2000).

Understanding the role of the environmental variables in the ecology of algae communities is one of the first steps for the adequate management of lotic ecosystems (Stevenson, 2009). This previous knowledge can lead to appropriate measures of using the benefits provided by the rivers, such as the multiple uses of water: public supply, navigation, recreation and fishing, among others.

Acknowledgements - The authors would like to thank the Coordenação de Aperfeiçoamento de Pessoal de Nível Superior - CAPES for funding the Master's Degree of the first author, and Dr. Pitágoras Augusto Piana and Dra. Susicley Jati for their valuable contributions to this work.

\section{References}

American Public Health Association - APHA. 1995. Standard methods for the examination of water and wasterwater. 19th ed. Washington: APHA.

BARBOSA, FAR., PADISÁK, J., ESPÍNDOLA, ELG., BORICS, G. and ROCHA, O. 1999. The cascading reservoir continuum concept (CRCC) and its application to the river Tietê-Basin, São Paulo State, Brazil. In TUNDISI, JG. and STRAKRABA, M. (Eds) Theoretical Reservoir Ecology and its Applications. São Carlos: International Institute of Ecology, Brazilian Academy of Sciences and Backhuys Publishers. p. 425-437.

BICUDO, CEM. and MENEZES, M. 2006. Gêneros de Algas de Águas continentais do Brasil: chave para identificação e descrições. São Carlos: Rima.

BORGES, PAF., RODRIGUES, LC., THOMAZ, AP. and TRAIN, S. 2003. Spatial variation of phytoplankton and some abiotic variables in Pirapó River-PR (Brazil) in August 1999: 
a preliminary study. Acta Scientiarum. Biological Sciences, vol. 26 , no. 1, p. 1-8.

BORICS, G., VÁRBÍRÓ, G., GRIGORSZKY, I., KRASZNAI, EK., SZABÓ, S. and KISS, KT. 2007. A new evaluation technique of potamo-plankton for the assessment of the ecological status of Rivers. Archives of Hydrobiology, vol. 161, no. 3-4 supplement, p. $465-486$.

BOVO-SCOMPARIN, VM. and TRAIN, S. 2008. Long-term variability of the phytoplankton community in an isolated floodplain lake of the Ivinhema River State Park, Brazil. Hydrobiologia, vol. 610, p. 331-344. http://dx.doi.org/10.1007/s10750-008-9448-3

BRASIL, 2011. Portal Brasil. Available from: <http://www.brasil. gov.br/sobre/geografia/mapas/hidrografia>. Access in: 12 Dec 2011.

BRASSAC, NM. and LUDWIG, TAV. 2006. Diatomáceas da Bacia do Rio Iguaçu, Paraná, Brasil: Pinnularia e Caloneis. Hoehnea, vol. 33, no. 2, p. 127-142.

CAVALCANTI, EAH. and LARRAZÁBAL, MEL. 2004. Macrozooplâncton da zona econômica exclusiva do nordeste do Brasil (segunda expedição oceanográfica - REVIZEE/NE II) com ênfase em Copepoda (Crustacea). Revista Brasileira de Zoologia, vol. 21, no. 3, p. 467-475. http://dx.doi.org/10.1590/ S0101-81752004000300008

CENTIS, B., TOLOTTI, M. and SALMASO, N. 2010. Structure of the diatom community of the River Adige (North- Eastern Italy) along a hydrological gradient. Hydrobiologia, vol. 639, p. 37-42. http://dx.doi.org/10.1007/s10750-009-0019-z

DESCY, JP. 1993. Ecology of the phytoplankton of the River Moselle: effects of disturbances on community structure and diversity. Hydrobiologia, no 249, p. 11-116.

DESCY, JP., LEITA, M., EVERBECQ, E., SMITZ, JS. and DELIÉGE, JF. 2011. Plankton of the River Loire, France: a biodiversity and modelling study. Journal of Plankton Research, p. 1-16.

DEVERCELLI, M. 2010. Changes in phytoplankton morphofunctional groups induced by extreme hydroclimatic events in the Midle Paraná River (Argentina). Hydrobiologia, vol. 639, p. 5-19. http://dx.doi.org/10.1007/s10750-009-0020-6

DOKULIL, MT. and TEUBNER, K. 2000. Cyanobacterial dominance in lakes. Hydrobiologia, vol. 438, p. 1-12. http:// dx.doi.org/10.1023/A:1004155810302

GUIMARÃES, AE., LOPES, CM., MELLO, RP. and ALENCAR, J. 2003. Ecologia de mosquitos (Díptera, Culicidae) em áreas do Parque Nacional do Iguaçu, Brasil: 1 - Distribuição por habitat. Caderno de Saúde Pública, vol. 19, no. 4, p. 11071116. PMid:12973575. http://dx.doi.org/10.1590/S0102311X2003000400032

HA, K., JANG, M. and JOO, G. 2002. Spatial and temporal dynamics of phytoplankton communites along a regulated river system, the Nakdong River, Korea. Hydrobiologia, vol. 470, p. 235-245. http://dx.doi.org/10.1023/A:1015610900467

HENRY, R. 1999. Ecologia de Reservatórios: Estrutura, Função e Aspectos Sociais. FAPESP/FUNDIBIO. 799 p.

Instituto Ambiental do Paraná - IAP. Bacia do Rio Iguaçu. Available from: <http://www.iap.pr.gov.br/arquivos/File/programas_e_projetos/ iguacu.pdf>. Access in: 20 Apr 2010.

JACKSON, DA. 1993. Stopping rules in principal component analysis. Ecology, vol. 74, p. 2204-214. http://dx.doi.org/10.2307/1939574
KOMÁREK, J. and ANAGNOSTIDIS, K. 1989. Modern approach to the classification system of Cyanophytes. 4 - Nostocales. Algological Studies, vol. 56, p. 247-345.

LAIR, N. and REYES-MARCHANT, P. 1997. The potamoplankton of the Middle Loire and the role of the 'moving littoral' in downstream transfer of algae and rotifers. Hydrobiologia, vol. 356, p. 33-52. http://dx.doi.org/10.1023/A:1003127230386

MAACK, R. 2002. Geografia física do Estado do Paraná. 3. ed. Rio de Janeiro: Livraria José Olympio. 438 p.

MARGALEF, R. 1983. Limnologia. Barcelona: Ediciones Omega. $1010 \mathrm{p}$.

McCUNE, B. and MEFFORD, MJ., 1999. PC-ORD. Multivariate analysis of ecological data, version 4.0. Gleneden Blach: MjM Software Design.

NOGUEIRA, MG., FERRAREZE, M., MOREIRA, ML. and GOUVÊA, RM. 2010. Phytoplankton assemblages in a reservoir cascade of a large tropical - subtropical river (SE, Brazil). Revista Brasileira de Biologia = Brazilian Journal of Biology, vol. 70, no. 3, p. 781-793. PMid:21085783. http://dx.doi.org/10.1590/ S1519-69842010000400009

O'FARRELL, I., LOMBARDO, RJ., PINTO, PT. and LOEZ, C. 2002. The assessment of water quality in the Lower Luján River (Buenos Aires, Argentina): phytoplankton and algal bioassays. Environmental Pollution, vol. 120, p. 207-218.100.

PERBICHE-NEVES, G., FERRAREZE, MF., SERAFIMJUNIOR, M., SHIRATA, MT. and LAGOS, PED. 2011. Influence of atypical pluviosity on phytoplankton assemblages in a strech of a large sub-tropical river (Brazil). Biologia Section Botany, vol. 66 , no. 1 , p. 33-41.

PIELOU, EC. 1966. The measurement of diversity in different types of biological collection. Journal of Theoretical Biology, no. 13, p. 131-144. PMid:5961533.

RAVEN, JA. and WAITE, AM., 2004. The evolution of silicification in diatoms: inescapable sinking and sinking as escape? New phytologist, vol. 162, p. 45-61. http://dx.doi.org/10.1111/j.14698137.2004.01022.x

REYNOLDS, CS. 1988. Potamoplankton: paradigms, paradoxes and prognoses. In ROUND, FE. (Ed.). Algae and Aquatic environment. Bristol: Biopress. p. 283-311.

-. 2006. Ecology of Phytoplankton. Cambridge: Ed. University Press. 535 p.

REYNOLDS, CS. and DESCY, JP. 1996. The production, biomass and structure of phytoplankton in large rivers. Archives of Hydrobiology, vol. 1-4, p. 161-187.

RODRIGUES, LC., TRAIN, S., BOVO-SCOMPARIN, VM., JATI, S., BORSALLI, CCJ. and MARENGONI, E. 2009. Interanual variability of phytoplankton in the main Rivers of the Upper Paraná River floodplain, Brazil: influence of upstream reservoirs. Revista Brasileira de Biologia $=$ Brazilian Journal of Biology, vol. 69, p. 501-516. PMid:19738958. http://dx.doi.org/10.1590/ S1519-69842009000300006

SALAMUNI, R., SALAMUNI, E., ROCHA, LA. and ROCHA, AL. 2002. Parque Nacional do Iguaçu, PR: Cataratas de fama mundial. In SCHOBBENHAUS, C., CAMPOS, DA., QUEIROZ, ET., WINGE, M. and BERBERT-BORN, MLC. (Eds.). Sítios Geológicos e Paleontológicos do Brasil. Brasília: DNPM/ CPRM - Comissão Brasileira de Sítios Geológicos e Paleobiológicos (SIGEP). p. 313-321. 
SALMASO, N. and ZIGNIN, A. 2010. At the extreme of physical gradients: phytoplankton in highly flushed, large rivers. Hydrobiologia, vol. 639, p. 21-36. http://dx.doi.org/10.1007/ s10750-009-0018-0

SCHEINER, SN. and GUREVITCH, J. 1993. Design and analysis of ecological experiment. New York: Chapman and Hall. 434 p.

Secretaria de Estado do Meio Ambiente e Recursos Hídricos - SEMA. 2010. Revista Bacias Hidrográficas do Paraná - Série Histórica, p. 1-140.

SHANNON, CE. and WEAVER, W. 1963. The mathematical theory of communication. Illinois: University Press, Urbana.

SILVA, CA., TRAIN, S. and RODRIGUES, LC. 2001. Estrutura e dinâmica da comunidade fitoplanctônica a jusante e montante do reservatório de Corumbá, Caldas Novas, Estado de Goiás, Brasil. Acta Scientiarum. Biological Sciences, vol. 23, no. 2, p. 283-290.

-. 2005. Phytoplankton assemblages in a Brazilian subtropical cascading reservoir system. Hydrobiologia, vol. 537, p. 99-109. http://dx.doi.org/10.1007/s10750-004-2552-0

SIMEPAR. 2011. Instituto Tecnológico Simepar. Previsão Climática para o Outono/2011. Available from: <http://www.simepar.br/ tempo/clima/clima.jsp>. Access in: 24 Nov 2011.

SOARES, MCS., HUSZAR, VLM. and ROLAND, F. 2007. Phytoplankton dynamics in two tropical river with different degrees of human impact (Southeast Brazil). River research and applications, vol. 23, p. 698-714. http://dx.doi.org/10.1002/rra.987

STATSOFT INC. 2005. Statistica (data analisys software system). version 7.1. Available from: <www.statsoft.inc>.
STEVENSON, RJ. 2009. Algae of River Ecosystems. In LIKENS, GE. (Ed.). River Ecosystem Ecology: a global perspective. San Diego: Academic Press. 411 p.

TRAIN, S., OLIVEIRA, MD. and QUEVEDO, MT. 2000. Dinâmica sazonal da comunidade fitoplanctônica de um canal lateral (Canal Cortado) do Alto Rio Paraná PR, Brasil). Acta Scientiarum. Biological Sciences, vol. 22, p. 389-395.

TWISS, MR., ULRICH, C., KRING, SA., HAROLD, J. and WILLIAMS, MR. 2010. Plankton dynamics along a $180 \mathrm{Km}$ reach of the Saint Lawrence River from its headwaters in Lake Ontario. Hydrobiologia, vol. 647, p. 7-20. http://dx.doi.org/10.1007/ s10750-010-0115-0

UTERMÖHL, H. 1958. Zur Vervollkommnung der quantitativen phytoplankton-methodic. Mitteilungen Internationale Vereinigung für Theoretische und Angewandte Limnologie, vol. 9, p. 1-38.

VANNOTE, RL., MINSHALL, GW., CUMMINS, KW., SEDELL, JR. and CUSHING, CE. 1980. The River Continuum Concept. Canadian Journal of Fisheries and Aquatic Sciences, vol. 37, p. 130-137. http://dx.doi.org/10.1139/f80-017

WEHR, JD. and DESCY, JP. 1998. Use of phytoplankton in large river management. Journal of Phycology, no. 34, p. 741-749.

ZALOCAR DE DOMITROVIC, Y., DEVERCELLI, M. and GARCIA DE EMILIANI, MO. 2007. Phytoplankton. In The Midle Paraná River: Limnology of a Subtropical Wetland. p. 177-203.

ZOHARY, T., PADISÁK, J. and NASELLI-FLORES, L. 2010. Phytoplankton in the physical environment: beyond nutrients, at the end, there is some light. Hydrobiologia, no. 639, p. 261-269. http://dx.doi.org/10.1007/s10750-009-0032-2 